\title{
Dynamic control on grain-size distribution of terri- genous sediments in the western South China Sea: Implication for East Asian monsoon evolution
}

\author{
CHEN GuoCheng ${ }^{\dagger}$, ZHENG HongBo, LI JianRu, XIE Xin \& MEI Xi
}

State Key Laboratory of Marine Geology, Tongji University, Shanghai 200092, China

High-resolution oxygen isotope stratigraphy of Core MD05-2901, which is located off eastern Vietnam in the western South China Sea (SCS), was established and indicated that the core spans a time period of the past $\mathbf{4 5 0} \mathrm{ka}$. Based on the bulk density, fractional porosity and lithogenic content of the sediments, terrigenous mass accumulation rate (TMAR) was obtained, which is $4.9-6.0 \mathrm{~g} \mathrm{~cm}^{-2} \mathrm{ka}^{-1}$ on average during interglacial stages, higher than that during glacial stages, i.e. $1.9-5.0 \mathrm{~g} \mathrm{~cm}^{-2} \mathrm{ka}^{-1}$, which is different from northern and southern SCS which show higher TMAR in glacial stages. By principle component analysis of grain size distribution of all the samples, two main control factors (F1 and F2) were obtained, which are responsible for about $\mathbf{8 0 \%}$ variance of granularity. The contents of grain size population $1.26-2.66 \mu \mathrm{m} \%$ and $10.8-14.3 \mu \mathrm{m} \%$ which are sensible to $\mathrm{F} 1$ show high-frequency fluctuation, and correlate well with the summer insolation at $15^{\circ} \mathrm{N}$. They exhibit a distinct cyclicity with frequencies near $23 \mathrm{ka}$ and $13 \mathrm{ka}$, in contrast to a strong frequency peak near $100 \mathrm{ka}$ obtained in proxies $4.24-7.42 \mu \mathrm{m} \%$ and $30.1-43.7 \mu \mathrm{m} \%$ controlled mainly by F2. The sedimentary character of this part of the SCS was controlled by variations of input flux from two main source areas, namely the southwest and north SCS, which were transported by different circulations of surface current forced by East Asian summer monsoon and winter monsoon respectively. We believe that the East Asian summer monsoon has fluctuated with high frequency and been forced by changes in solar insolation in low latitude associated with precession and half precession, while ice-volume forcing is probably a primary factor in determining the strength and timing of the East Asian winter monsoon but with less important insolation forcing.

South China Sea, late Quaternary, terrigenous sediments, grain size, East Asian monsoon

As the significant component of the global climate, the finer details of East Asian monsoon are now coming to light through investigation of records from land and sea. The South China Sea, the largest marginal sea in the western Pacific, gives us the ideal materials to trace East Asian monsoon evolution, because it received abundant terrigenous products of chemical weathering and physical erosion in adjacent continents ${ }^{[1]}$. Through the research on the deep sea sediments, especially the sediment cores collected in ODP 184 cruise, abundant information about the tectonic history of the South China Sea and East Asian monsoon evolution during the Ce- nozoic has become known ${ }^{[1-4]}$. More and more paleo-oceanographic information such as changes of thermocline depth, sea water temperature and paleoproductivity, has been discovered mainly by studies on biogenic materials ${ }^{[5-9]}$.

The South China Sea, a semi-closed basin with the

\footnotetext{
Received August 31, 2007; accepted November 5, 2007 doi: 10.1007/s11434-008-0078-y

'Corresponding author (email: gcchen6@yahoo.com.cn)
}

Supported by the National Natural Science Foundation of China (Grant No. 40676033), the National Key Basic Research Special Foundation Project of China (Grant No. 2007CB815906) and the Funds for Creative Research Groups of China (Grant No. 40621063) 
Asian continent and Taiwan lying in the north and west, and the volcanic islands in the south and east, is characterized by much higher terrigenous mass accumulation rate than open oceans. And the continental materials contain lots of information about tectonic sedimentary history, chemical weathering and physical erosion, and East Asian monsoon evolution ${ }^{[1]}$. However, the studies on terrigenous sediments have not been paid enough attention relative to biogenic materials ${ }^{[10,11]}$.

Grain-size distribution of terrigenous sediments preserves abundant information about source area, transport and sedimentation processes. Grain-size distribution of loess sediments has been widely used to study the East Asian monsoon evolution ${ }^{[12-20]}$. Much knowledge about global and regional climate has been gained by extracting different grain-size components of sediments. Grain-size distribution of marine sediments also provides much information about changing environment such as source region's climate, monsoon evolution and ocean currents, which was well applied to studies in the north Atlantic ${ }^{[21]}$, the north Pacific ${ }^{[22]}$, Arabian Sea ${ }^{[23,24]}$, offshore southwest coast of Africa ${ }^{[25,26]}$, the East China Sea ${ }^{[27]}$, the South China Sea ${ }^{[28]}$ and so on. In order to track the changes of the past environment, it is critical to extract grain-size populations sensitive to environment and their characteristics (such as mode, range of grain-size distribution, content of different populations, etc.). Recently scientists have developed many mathematical methods to partition grain-size populations of sediments, which mainly include fitting function based on Weibull distribution ${ }^{[29]}$, endmember modeling of grain-size $e^{[23-25,30,31]}$, and grain-size vs. standard deviation ${ }^{[28,32]}$.

In this paper, we report the grain-size analytical results of the deep sea terrigenous sediments from Core MD05-2901 in the western South China Sea (Figure 1). Additionally, based on the high-resolution oxygen isotope stratigraphy combined with other physical parameters, the variation trend of terrigenous mass accumulation rate over the past $450 \mathrm{ka}$ was calculated. Here we present a new method, namely the principle component analysis, to extract grain-size populations sensitive to sedimentary environments, and to further analyze dynamic control on grain-size distribution of terrigenous sediments in the western South China Sea during late Quaternary, to study the history and mechanism of East Asian summer monsoon and winter monsoon evolution.

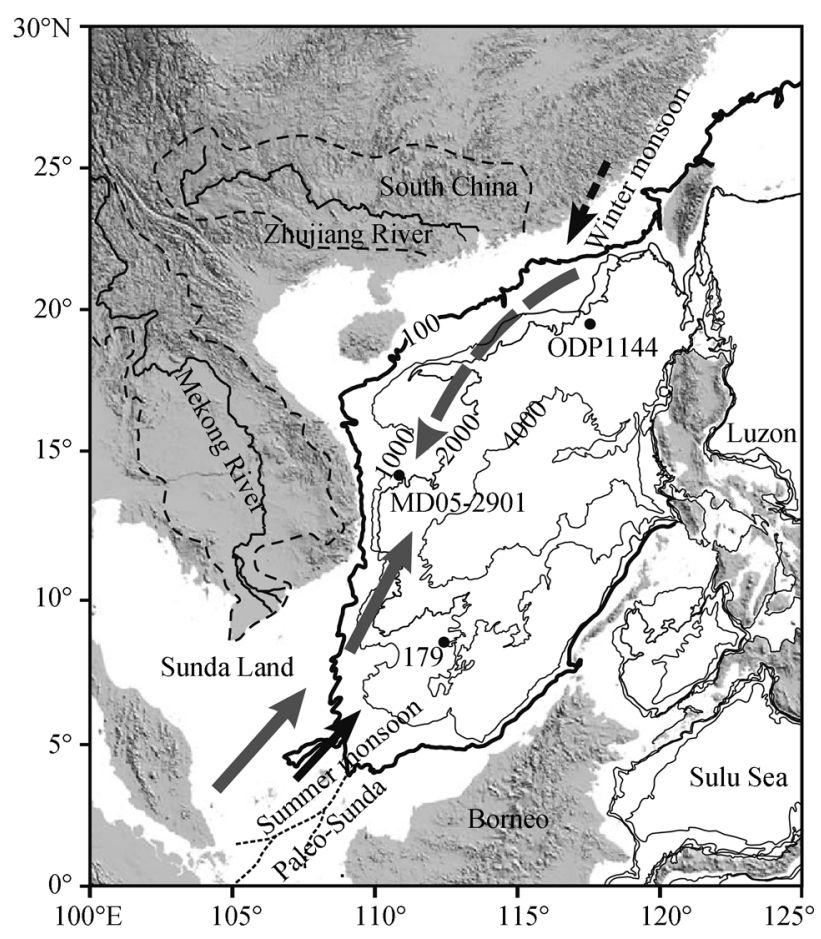

Figure 1 Bathymetry of the South China Sea and location of Core MD05-2901. Gray solid arrows indicate the surface current forced by summer monsoon and gray dashed arrows present the surface current drived by winter monsoon. The drainage area of Zhujiang River and Mekong River and locations of some other cores mentioned in the study are also displayed.

\section{Materials, methods and age model}

\subsection{Introduction to Core MD05-2901}

Core MD05-2901 $\left(14^{\circ} 22.50^{\prime} \mathrm{N}, 110^{\circ} 44.60^{\prime} \mathrm{E}\right.$, water depth $1454 \mathrm{~m}$, core length $36.49 \mathrm{~m}$ ) was collected from the western slope of the South China Sea during the international cruise Marco Polo (IMAGES XII). The core consists of olive green or green gray hemipelagic mud sediments enriched with well-preserved calcareous and siliceous microfossils without obvious disturbance. No turbidites were detected. The section between 13.65 and $14.35 \mathrm{~m}$ was absent because of the shipboard coring disturbance. Magnetic susceptibility, bulk density, fractional porosity, colour reflectance, etc. were measured on board. The detailed procedures of sampling and measurements and the physical parameter results are included in Marco Polo cruise report ${ }^{[33]}$.

\subsection{Oxygen isotope stratigraphy}

Oxygen isotope compositions $\left(\delta^{18} \mathrm{O}\right)$ have been measured with $8 \mathrm{~cm}$ intervals on planktonic foraminifera $G$. rubber (white) using a Finnigan MAT252 mass spectrometer in the State Key Laboratory of Marine Geology, 
Tongji University. The measurements are reported versus PDB with a mean external reproducibility of $\pm 0.08 \%$. The age model has been established mainly by using the high-resolution oxygen isotopic stratigraphy combined with the first and last occurrences of G. rubber (pink) at $3337 \mathrm{~cm}$ (404 ka in age) and $1273 \mathrm{~cm}$ (120 ka in age ${ }^{[34]}$, respectively. The chronology was finally established by correlating to the benthic foraminifera oxygen isotope stratigraphy at the Ocean Drilling Program (ODP) Site $677^{[35]}$. The result indicates that the bottom of Core MD05-2901 is located in marine oxygen isotope stage (MIS) 12, with an approximate age of 447 ka.

\subsection{Grain-size measurement}

A total of 912 samples with a depth resolution of $4 \mathrm{~cm}$ were taken from the core for grain-size measurement following the methodology of ref. [36]. First, take $0.15 \mathrm{~g}$ sample, and input $10 \mathrm{~mL} 30 \% \mathrm{H}_{2} \mathrm{O}_{2}$, in order to remove organic matter; second, add $15 \mathrm{~mL} 25 \%$ acetic acid, boiling for $1 \mathrm{~min}$, then shift to $1000 \mathrm{~mL}$ beaker with full purified water, stabilizing for $24 \mathrm{~h}$ to remove carbonate; Third, shift to $300 \mathrm{~mL}$ beaker, and add $6 \mathrm{~g} \mathrm{NaOH}$, boiling for $5 \mathrm{~min}$, then shift to $1000 \mathrm{~mL}$ beaker with full purified water, stabilizing for $24 \mathrm{~h}$ to remove biogenic silica. Forth, shift to $300 \mathrm{~mL}$ beaker, add $300 \mathrm{mg}$ $\left(\mathrm{NaPO}_{3}\right)_{6}$, boiling for $1 \mathrm{~min}$, then scatter it using ultra-sonic for $3 \mathrm{~min}$. Finally, the samples were measured on a Laser Particle Size Analyzer Beckman Coulter LS230 at the State Key Laboratory of Marine Geology, Tongji University.

\section{Results}

\subsection{Terrigenous mass accumulation rate}

According to sub-bottom seismic profile ${ }^{[33]}$, the sedimentary environment in the coring area is very stable, and turbidity is absent. It indicates that the terrigenous detrital particles have settled stably. The marine sediments consist of biogenic materials such as foraminifer, opal and diatom, and terrigenous clastics that comprise mainly of different types of detrital minerals like clay minerals and quartz. In order to understand sedimentary mechanism of the terrigenous clastics, here we calculated the terrigenous mass accumulation rate (TMAR) with unit $\mathrm{g} \mathrm{cm}^{-2} \mathrm{ka}^{-1}$ as follows ${ }^{[37]}$ :

$$
\mathrm{TMAR}=\mathrm{SR} \times(\mathrm{BD}-\mathrm{P} \times \mathrm{WD}) \times \mathrm{wt} \%,
$$

where $\mathrm{SR}$ is the linear sedimentation rate with unit $\mathrm{cm} / \mathrm{ka}$. BD is bulk density of sediment with unit $\mathrm{g} / \mathrm{cm}^{3}$, measured on board using Teotek Multi-Sensor-CoreLogger ${ }^{[33]}$. WD is density of sea water, $1.025 \mathrm{~g} / \mathrm{cm}^{3}$. $\mathrm{wt} \%$ is weight percentage of terrigenous sediment which is from ref. [9].

$P$ is fractional porosity, calculated by using the following formula ${ }^{[38]}$ :

$$
P=0.7263 \times \mathrm{e}^{-z / 1064},
$$

where $z$ is the depth of the sample below sea floor.

The TMAR varied with time in a range of $1-10 \mathrm{~g}$ $\mathrm{cm}^{-2} \mathrm{ka}^{-1}$ (Figure 2). The average value of TMAR in glacial stages is $4.9-6.0 \mathrm{~g} \mathrm{~cm}^{-2} \mathrm{ka}^{-1}$, higher than $1.9-$ $5.0 \mathrm{~g} \mathrm{~cm}^{-2} \mathrm{ka}^{-1}$ in interglacial stages. Especially since MIS7, TMAR shows strong glacial-interglacial cycles, and more terrigenous clastics settled in this area during interglacial stages with the highest value $10 \mathrm{~g} \mathrm{~cm}^{-2} \mathrm{ka}^{-1}$. The sedimentary characteristics in the western South China Sea is different from that in the north South China Sea and in the south South China Sea. For example, TMAR exhibits a higher value in glacial stages in Core $17961^{[2]}$ and Core ODP1144 $4^{[28]}$, which is the main sedimentary trend in the South China Sea ${ }^{[39]}$.

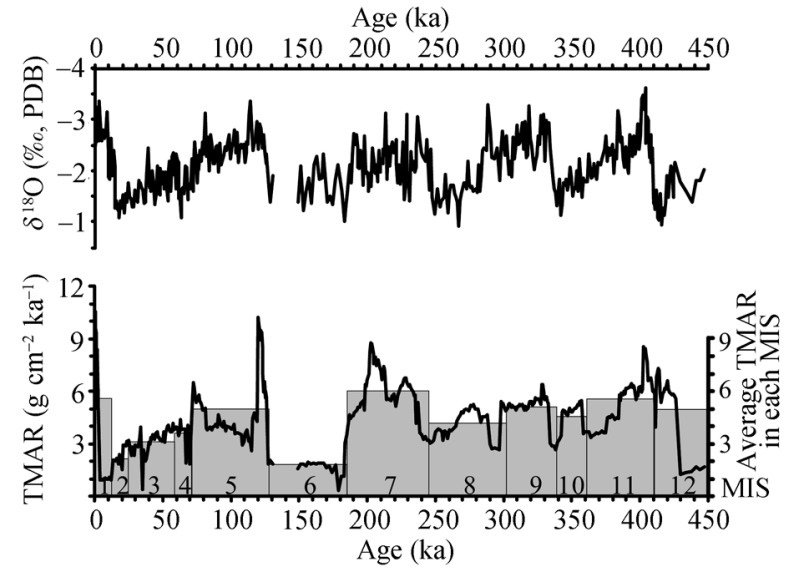

Figure 2 Terrigenous mass accumulation rate (TMAR) and planktonic foraminifera oxygen isotope stratigraphy over the past $450 \mathrm{ka}$ of Core MD05-2901. The average TMAR in each MIS is also presented.

\subsection{Principle component analysis of grain-size data}

In scientific research, we usually have a big set of data and want to analyze the set in terms of the relationships between the individual points in the data set. It is very important to find a feasible analytical method that reduces the data without loss of the information contained in the data. Principle component analysis is a common useful statistical technique for finding information in data of high dimension. The main applications of this kind of factor analytic technique are: (1) to reduce the 
number of variables and (2) to detect structure in the relationships between variables, that is to classify variables.

Table 1 Correlation coefficients between content of each grain-size fraction in the range of $0-60 \mu \mathrm{m}$ and the two main control factors (F1 and F2) at Core MD05-2901

\begin{tabular}{ccc||ccc}
\hline Grain size $(\mu \mathrm{m})$ & F1 & F2 & Grain size $(\mu \mathrm{m})$ & F1 & F2 \\
\hline 0.38 & 0.735 & 0.392 & 5.11 & 0.181 & -0.941 \\
0.41 & 0.734 & 0.392 & 5.61 & 0.057 & -0.953 \\
0.45 & 0.734 & 0.396 & 6.16 & -0.071 & -0.944 \\
0.50 & 0.736 & 0.405 & 6.76 & -0.202 & -0.911 \\
0.54 & 0.741 & 0.419 & 7.42 & -0.334 & -0.852 \\
0.60 & 0.747 & 0.434 & 8.15 & -0.469 & -0.760 \\
0.66 & 0.754 & 0.451 & 8.94 & -0.601 & -0.627 \\
0.72 & 0.762 & 0.467 & 9.82 & -0.716 & -0.451 \\
0.79 & 0.771 & 0.485 & 10.8 & -0.796 & -0.243 \\
0.87 & 0.781 & 0.500 & 11.8 & -0.831 & -0.028 \\
0.95 & 0.791 & 0.509 & 13.0 & -0.829 & 0.169 \\
1.05 & 0.802 & 0.510 & 14.3 & -0.803 & 0.333 \\
1.15 & 0.814 & 0.498 & 15.7 & -0.772 & 0.455 \\
1.26 & 0.826 & 0.474 & 17.2 & -0.749 & 0.534 \\
1.38 & 0.838 & 0.435 & 18.9 & -0.741 & 0.574 \\
1.52 & 0.849 & 0.380 & 20.7 & -0.742 & 0.587 \\
1.67 & 0.860 & 0.311 & 22.7 & -0.730 & 0.588 \\
1.83 & 0.868 & 0.227 & 25.0 & -0.697 & 0.594 \\
2.01 & 0.872 & 0.128 & 27.4 & -0.650 & 0.618 \\
2.21 & 0.867 & 0.013 & 30.1 & -0.599 & 0.661 \\
2.42 & 0.851 & -0.115 & 33.0 & -0.545 & 0.708 \\
2.66 & 0.821 & -0.254 & 36.2 & -0.485 & 0.737 \\
2.92 & 0.772 & -0.396 & 39.8 & -0.421 & 0.721 \\
3.21 & 0.705 & -0.535 & 43.7 & -0.361 & 0.660 \\
3.52 & 0.620 & -0.661 & 47.9 & -0.307 & 0.572 \\
3.86 & 0.522 & -0.767 & 52.6 & -0.249 & 0.474 \\
4.24 & 0.414 & -0.849 & 57.8 & -0.173 & 0.387 \\
4.66 & 0.300 & -0.906 & & & \\
\hline & & & & & \\
\hline
\end{tabular}

Sedimentary characteristics of terrigenous clastics in the marine sediments are controlled by source area, transport and sedimentation processes, which of course effect the grain-size distribution of the sediments. In this paper, principle component analysis, a powerful tool for factor analysis, was used to analyze the grain-size data of all samples in order to extract grain-size populations sensitive to environment, and further to understand the dynamic control on sedimentation in this area. All the particles above $60 \mu \mathrm{m}$ were not considered, because their content is almost below $0.1 \%$ for all samples. In order to do principle component analysis of grain-size data, a database of all the samples is constructed, in which the grain-size in the range of $0-60 \mu \mathrm{m}$ is subdivided into 55 fractions (Table 1), and the content of each grain-size fraction is used as a variable. Here we used
SPSS13 (Statistical Package for the Social Science, a world-famous statistical and analytical software) to do principle component analysis.

Two main control factors (F1 and F2), which are responsible for $46 \%$ and $32 \%$ variance of the grain-size distribution of all the samples respectively, were obtained. The correlation coefficients in Table 1 reflect the intensity of relationship between the content of each grain-size fraction and the two factors. Positive number (negative) indicates positive (negative) correlation. The bigger the number's absolute value is, the more representative this grain-size fraction is to this factor. Taking the $2.01 \mu \mathrm{m}$ for example, its load on factor F1 is 0.872 , and its load on factor F2 is 0.128 . It means that the variation of the content of this grain-size fraction is mainly controlled by F1, but much less by F2. The loads figure (Figure 3) can visually reflect the intensity of correlation between each grain-size fraction and the two factors. It was obtained through projecting each grain-size fraction's load to the two axes of F1 and F2. As shown in Table 1 and Figure 3, the 9 grain-size fraction between 1.26 and 2.66 and the 4 grain-size fraction between 10.8 and 14.3 are sensitive to F1, but not to F2. Whereas, the 7 grain-size fraction between 4.24 and 7.42 and the 5 grain-size fraction between 30.1 and 43.7 are sensitive to F2, but not to F1.

The variations of $1.26-2.66 \mu \mathrm{m} \%, 10.8-14.3 \mu \mathrm{m} \%$, $4.24-7.42 \mu \mathrm{m} \%$ and $30.1-43.7 \mu \mathrm{m} \%$ over the past $450 \mathrm{ka}$ is shown in Figure 4. $1.26-2.66 \mu \mathrm{m} \%$ and

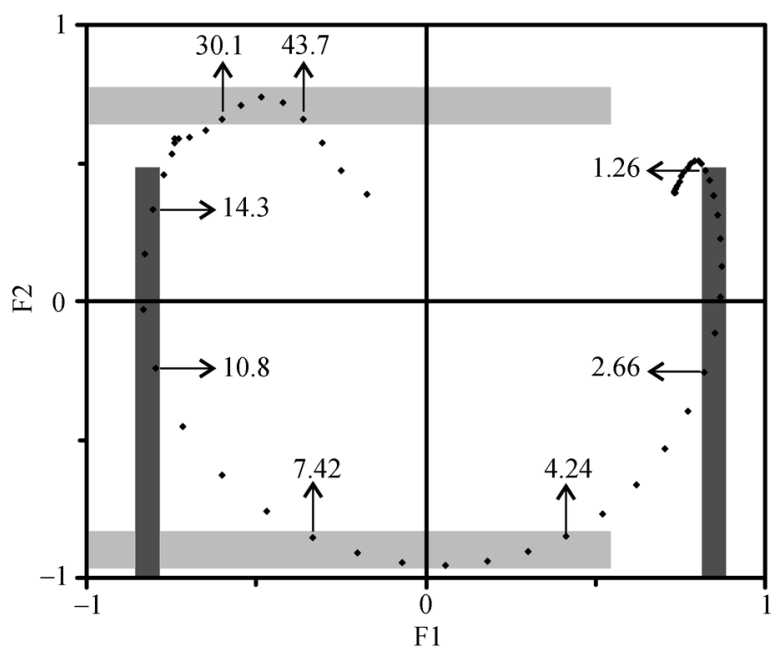

Figure 3 Correlation coefficients between content of each grain-size fraction in the range of $0-60 \mu \mathrm{m}$ and the two main control factors (F1 and F2) at Core MD05-2901. The grain-size fraction in deep gray area is mainly controlled by F1, while the grain-size fraction in light gray area is mainly controlled by F2. 


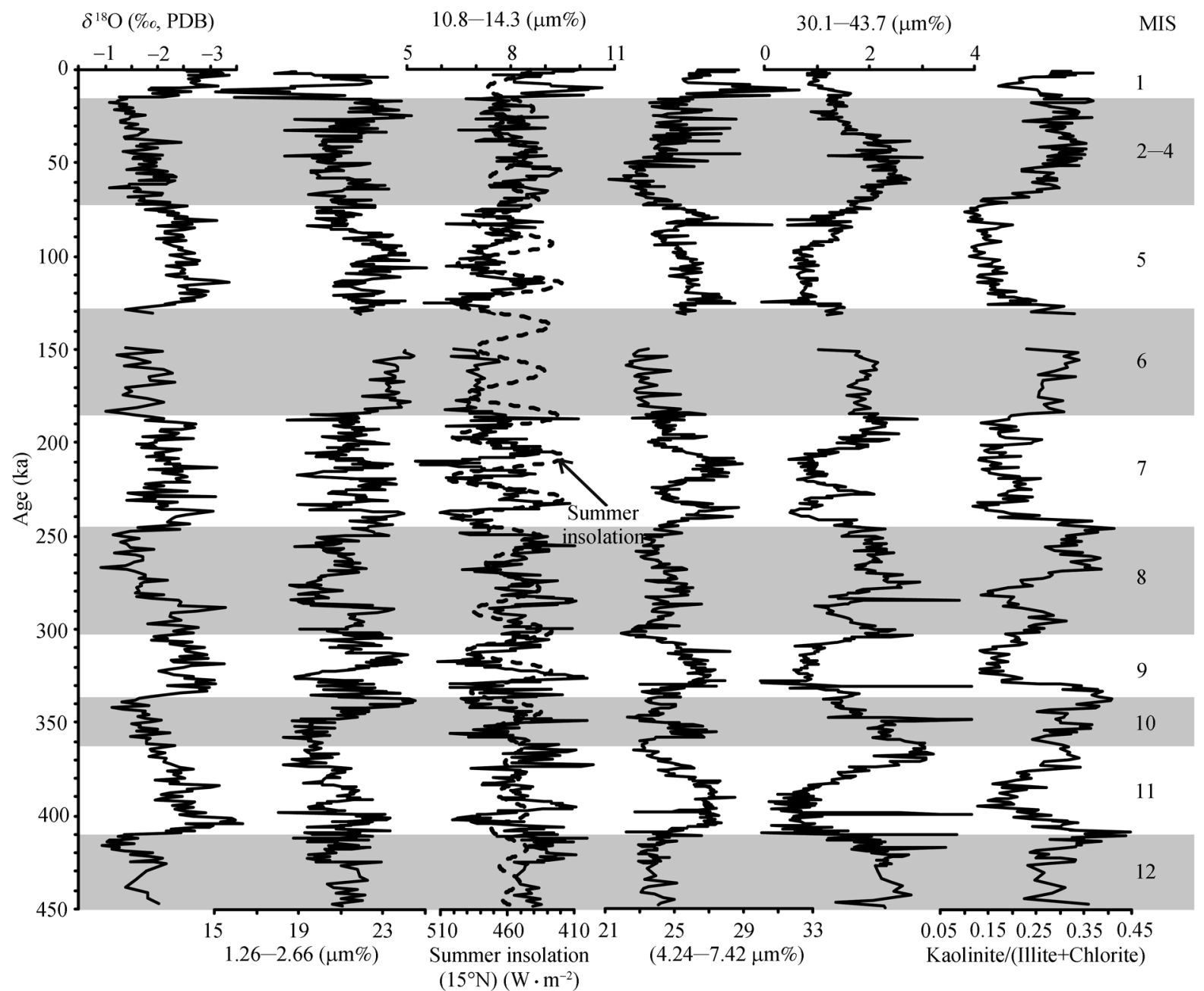

Figure $41.26-2.66 \mu \mathrm{m} \%, 10.8-14.3 \mu \mathrm{m} \%, 4.24-7.42 \mu \mathrm{m} \%, 30.1-43.7 \mu \mathrm{m} \%$ and planktonic foraminifera oxygen isotope stratigraphy over the past $450 \mathrm{ka}$ at Core MD05-2901, and the comparison between the grain-size proxies and the kaolinite/(illite+chlorite) ratio and the summer insolation of low latitude in the Northern Hemisphere. The summer insolation refers to an average insolation during July at $15^{\circ} \mathrm{N}$ following the Laskar solution ${ }^{[40]}$, using the Analyserie software ${ }^{[41]}$.

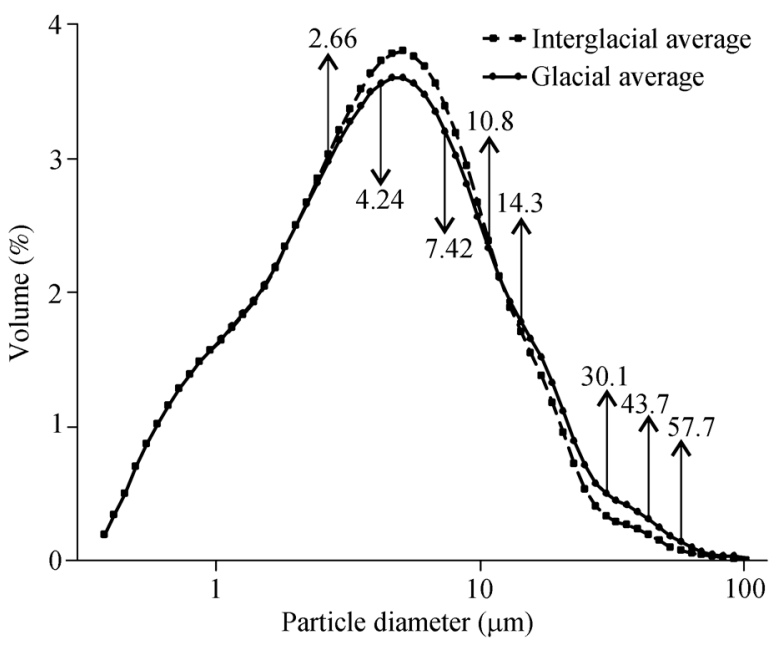

Figure 5 The average grain-size distribution of interglacial samples and glacial samples from Core MD05-2901.
$10.8-14.3 \mu \mathrm{m} \%$ shows high-frequency fluctuation and obvious negative correlation, because the two populations correlate with F1 positively and negatively respectively. For the same reason, $4.24-7.42 \mu \mathrm{m} \%$ and $30.1-43.7 \mu \mathrm{m} \%$ also exhibit an obvious negative correlation. They are in accordance with oxygen isotope, and show clear glacial-interglacial cyclicity. Even in interstadials of MIS 5 and MIS 7, the two populations also had strong correspondence.

Interglacial and glacial average grain-size distribution curves are achieved through averaging every grain-size fraction's contents of all the samples (Figure 5). Whatever glacial samples or interglacial samples, the average content of particles above $60 \mu \mathrm{m}$ is very little, less than $0.1 \%$. The average content of each grain-size fraction in 
the ranges of $0-2.66 \mu \mathrm{m}$ and $10.8-14.3 \mu \mathrm{m}$ in interglacial and glacial samples are nearly the same, which indicates that the two populations do not show a glacial-interglacial cyclicity. For each grain-size fraction in the population of $4.24-7.42 \mu \mathrm{m}$, the content in interglacial stages is higher than that in glacial stages. Meanwhile, for the population of $30.1-43.7 \mu \mathrm{m}$, the content in glacial stages is higher than that in interglacial stages. So we can conclude that the two populations of 4.24$7.42 \mu \mathrm{m}$ and $30.1-43.7 \mu \mathrm{m}$ vary on the scale of glacial-interglacial cycles. The conclusion is consistent with the results of principle component analysis of grain-size distribution data.

\section{Discussion}

\subsection{Source of terrigenous materials and dynamic control}

The South China Sea has broad continental shelves in the north and southwest, which emerged or disappeared with the sea level changes during glacial-interglacial cycles in late Quaternary ${ }^{[1]}$. The marine sediments in the South China Sea consist mainly of calcareous and siliceous microfossils and rich lithogenic products of chemical weathering and physical erosion in adjacent continents, which provide a good record of East Asian monsoon evolution and paleoceangraphy information such as sea current changes in the past.

The northern continental shelf is very broad and flat with very low gradient. The southwestern South China Sea is the channel to the Indian Ocean which is only $30-50 \mathrm{~m}$ deep. While the sea level decreased, the Sunda shelf emerged broadly and the channel shut down, and made the South China Sea become a semi-closed sea basin. The sea level could decrease about $120-140 \mathrm{~m}$ in glacial stages ${ }^{[42,43]}$. It generated broad exposure of continental shelves and moving ahead of estuaries of the Zhujiang River and Mekong River that would favor the transport of terrigenous materials to adjacent continental slope and sea floor. Controlled by the regular changes of sea level and river input, the TMAR showed glacialinterglacial cycles. In the northern and southern South China Sea, the sedimentation rate in glacial stages is higher than that in interglacial stages, which was the case for Core $17961^{[2]}$ and Core ODP1144 $4^{[28]}$. Because the exposure of more continental shelves and moving ahead of estuaries to sea produced more terrigenous ma- terials, combined with the shortened distance between estuaries and the deep sea, it was easier to transport more materials to hemipelagic areas in glacial stages.

According to the studies of pollen ${ }^{[44]}$ and charcoal ${ }^{[45]}$ records from the northern South China Sea, the climate was relatively cold and dry, and the emerging continental shelf was mainly covered by grass vegetation in glacial stages. Grain-size distribution of carbonate-free fraction of sediments form Core ODP1144 exhibits significant variation between glacial and interglacial changes, suggesting a higher proportion of coarse particles in glacial stages ${ }^{[28]}$. It indicates that the northern continental shelf was mainly controlled by strong physical erosion, but weak chemical weathering during glacial stages.

The contribution of eolian dust to the marine sediments in the South China Sea needs further studies. The dust from the Loess Plateau in China could be entrained to an elevation of $>5000 \mathrm{~m}$, moved north and northwestward, ultimately reaching $50^{\circ} \mathrm{N}$, where the dust was transported by the westerly jet stream mainly to the remote high latitude area ${ }^{[46]}$, like north Pacific ${ }^{[22]}$. However, modern meteorological investigation discovered that the Asian inland dust can be transported to Hong Kong by strong dust storms. Therefore, we suggest that the contribution of dust to the sediments in middle and high latitude areas was relatively obvious which otherwise has not been quantitatively estimated. Relatively large contribution of eolian dust for the total marine sediment accumulation was previously reported for the northern part of the South China Sea ${ }^{[2,47,48]}$. The dust possibly came from adjacent continental shelf. In glacial stages, large continental shelf north to the South China Sea exposed in the relatively dry and cold climate and strong winter monsoon ${ }^{[2]}$. They all favored the production and transport of eolian dust, which is possibly one of the reasons why the particles in glacial stages became coarse in the north of the South China Sea. The western South China Sea is adjacent to the very narrow continental shelf in Middle Vietnam and far from the northern continental shelf. The obvious contribution of dust to the sediments in this area has not been previously reported ${ }^{[11]}$. The grain-size distribution of most sediment samples from Core MD05-2901 exhibits single mode, which indicates that the influence of eolian dust was little, if existed. Additionally, some tiny volcanic dusts originated from Luzon Island could arrive at this area ${ }^{[49]}$ because of the prevailing westward wind in high-eleva- 
tion sky at $15^{\circ} \mathrm{N}^{[50]}$. The volcanic dust caused high magnetic susceptibility values and double mode of grain-size distribution of some samples, and was also responsible for the peaks of $30.1-43.7 \mu \mathrm{m} \%$ curve $^{[51]}$.

Studies on clay minerals of Core MD05-2901 confirmed the sedimentation of terrigenous materials originated from Red River and Zhujiang River on the northern shelf through the transport of anti-clockwise current forced by winter monsoon ${ }^{[11]}$. The content of kaolinite mainly from Zhujiang River exhibits strong glacial-interglacial cyclicity ${ }^{[11]}$. The southwestern continental shelf, Sunda shelf near the South China Sea, had different climate environments from the northern continental shelf. Tropical lowland rainforest and mangroves grew on the Sunda shelf, which indicates that the Sunda shelf experienced only a marginally lower temperature but not drier than today ${ }^{[49]}$. The smectite that was supplied mainly by Mekong River and paleo-rivers on Sunda shelf exhibits high-frequency fluctuation ${ }^{[11]}$. We can conclude that the supply of terrigenous materials from the southwestern source area did not exhibit glacial-interglacial cycles, which was different from that of the northern source area.

Previous studies once suggested that mountain belts in Middle Vietnam are the major source of terrigenous clastics in the western South China Sea ${ }^{[52]}$. Small mountainous rivers may input huge continental clastics to the ocean because of their special geomorphology and tectonics ${ }^{[53]}$. For example, although rivers surrounding Taiwan have small drainage areas, their physical erosion rate may be the highest in the world and discharge $185 \times 10^{6}$ t suspended sediment annually ${ }^{[54]}$. The rainstorm was reported as the most important forcing factor of denudation in Taiwan ${ }^{[55]}$. But the situation of mountain in Middle Vietnam is very different. When blowing over the Indochina Peninsula, the southwesterly summer monsoon, which is situated in the transition zone between South Asian and East Asian monsoons, released rain mainly in western Indochina and on the western slope of mountains in Middle Vietnam. The runoff on the eastern slope may actually be very low. In addition, the rivers' drainage area is very small (Figure 1), therefore large sediment discharge to the sea could not happen here. Grain-size distribution of terrigenous clastics indicates that the particles larger than $60 \mu \mathrm{m}$ are very few, and the mean grain-size is only $6-8 \mu \mathrm{m}$, which also confirmed the impossibility of sediment discharge from the nearby mountains in Middle Vietnam.

The variation of grain-size distribution of terrigenous clastics at Core MD05-2901 was mainly controlled by two factors, F1 and F2, which represent the different clastics provenances and transport processes that originated from southwestern and northern continental shelves respectively. In glacial-interglacial cycles, the sea surface current pattern in the South China Sea experienced significant changes because of coastline's changes and evolution of East Asian monsoon ${ }^{[1,56]}$. In interglacial stages, the southwesterly clockwise sea surface currents forced by winds in summer was prominent (Figure 1), and transported more terrigenous clastics originated from southwestern continental shelf to this area. In contrast, the South China Sea was characterized mainly with strong anticlockwise sea surface currents forced by winter monsoon in glacial stages (Figure 1), which brought relatively more materials from northern continental shelf. Because of different climate environments of source area, sea current intensity, and transport distance, the grain-size distribution of terrigenous clastics from northern continental shelf is quite different from that from the southwestern continental shelf. And different grain-size fraction has different sensitivity to the two different processes, as shown in Table 1 and Figure 3. $1.26-2.66 \mu \mathrm{m} \%$ and $10.8-14.3 \mu \mathrm{m} \%$ sensitive to $\mathrm{F} 1$ exhibit high-frequency fluctuation. It may correlate with the southwestern source, since the two populations are relatively thin. In contrast, the glacial-interglacial cyclicity dominates the variations of $4.24-7.42 \mu \mathrm{m} \%$ and $30.1-43.1 \mu \mathrm{m} \%$ sensitive to $\mathrm{F} 2$, which is related with the northern source. Moreover, the estuary of Mekong River is closer to this area, and TMAR is higher in interglacial stages which are characterized with clockwise sea surface current. It indicates that the terrigenous materials input from southwestern source were relatively high. As mentioned above, F1 is responsible for $46 \%$ variation of grain-size distribution, and $\mathrm{F} 2$ for $32 \%$, which also confirmed that F1 and F2 correlate with southwestern source and northern source respectively.

\subsection{East Asian monsoon evolution implicated by grain-size proxy}

The above analysis indicates that the two main controlling factors actually reflect the variation of terrigenous clastics input from different sources that was influenced by sea surface currents. They controlled the changes of 
grain-size distribution of terrigenous clastics of Core MD05-2901 over the past $450 \mathrm{ka}$. The surface circulations in the South China Sea are forced mainly by the East Asian monsoon, with clockwise or anticlockwise surface current driven by summer or winter monsoon respectively ${ }^{[56]}$. Thus, F1 and F2 can reflect variations on prevailing monsoons in the western South China Sea. On the one hand, the southwesterly surface current forced by the summer monsoon carried relatively fine terrigenous clastics provided mainly by southwestern source through intense chemical weathering to the western South China Sea; on the other hand, the anticlockwise surface current forced by the winter monsoon transported relatively coarse terrigenous clastics originated mainly from northern source by strong physical erosion to the western South China Sea. The content of each grain-size fraction in the population $1.26-2.66 \mu \mathrm{m}$ $(10.8-14.3 \mu \mathrm{m})$ has high positive (negative) correlation with F1. Therefore, higher 1.26-2.66 $\mu \mathrm{m} \%$ (10.8$14.3 \mu \mathrm{m} \%$ ) indicates the strong (weak) summer monsoon. For the same reason, higher $30.1-43.7 \mu \mathrm{m} \%$ (4.24-7.42 $\mu \mathrm{m} \%$ ) mainly indicates the strong (weak) winter monsoon.

$1.26-2.66 \mu \mathrm{m} \%$ and $10.8-14.3 \mu \mathrm{m} \%$ for terri-
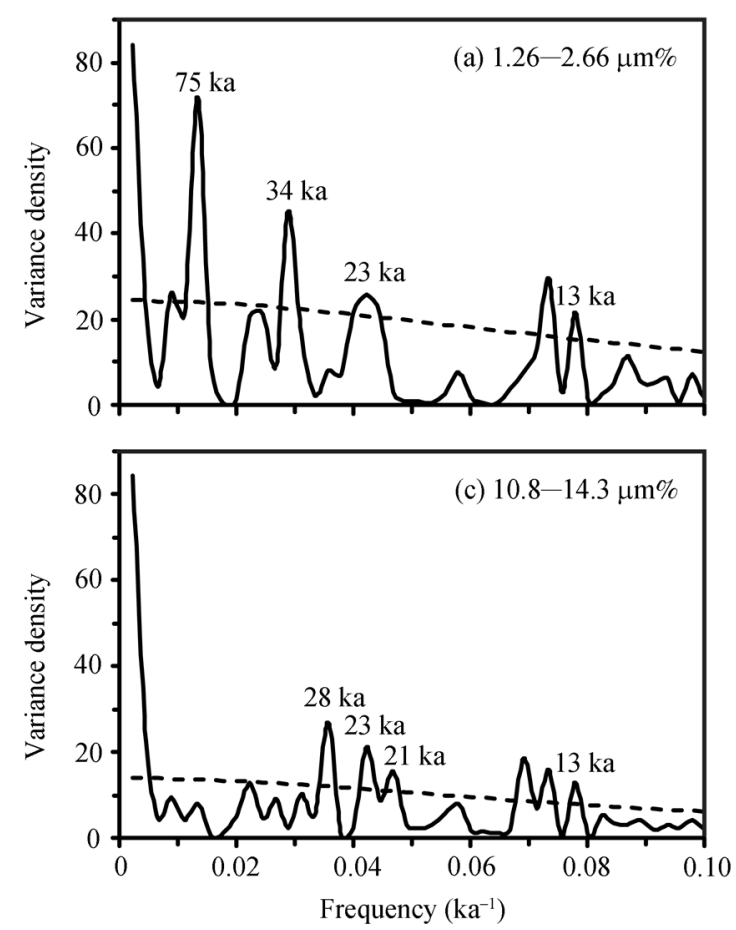

genous clastics from Core MD05-2901 exhibit high frequency fluctuation over the past $450 \mathrm{ka}$ (Figure 4). Their spectral analysis presents 23 -ka precession period and 13-ka semi-precession period as well (Figure 6(a), (c)). This is the same as the spectral analysis results of other East Asian summer monsoon proxies ${ }^{[11]}$. The precession and semi-procession period is a character of the tropical process ${ }^{[57]}$, indicating the feature of low-latitude summer monsoon evolution. $30.1-43.7 \mu \mathrm{m} \%$ and $4.24-7.42$ $\mu \mathrm{m} \%$ show an obvious glacial-interglacial cyclicity (Figure 4). They have a strong 100-ka eccentricity period (Figure 6(b), (d)), which is the main feature effected by high-latitude ice sheet. It indicates that the East Asian monsoon's evolution was controlled by high-latitude ice sheet, which further confirms the close relation between the winter monsoon records in the South China Sea and glacial cycles ${ }^{[4]}$. In addition, $30.1-43.7 \mu \mathrm{m} \%$ and $4.24-7.42 \mu \mathrm{m} \%$ also show the 23 -ka precession period. It because that the content of terrigenous clastics from southwestern source varied with large amplitude, which effects the relative content of other materials.

The ratio of kaolinite/(illite+chlorite) of Core MD052901 was reported as a mineralogical indicator of the East Asian winter monsoon evolution ${ }^{[11]}$. The good cor-
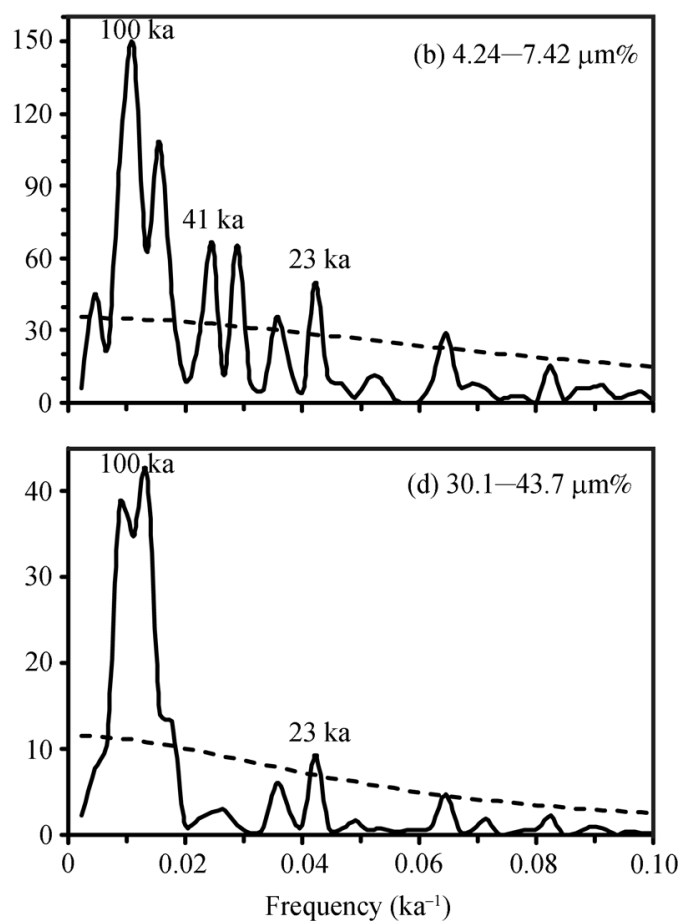

Figure 6 Spectral analysis results of different grain-size proxies at Core MD05-2901. (a) $1.26-2.66 \mu \mathrm{m} \%$; (b) $4.24-7.42 \mu \mathrm{m} \%$; (c) $10.8-14.3 \mu \mathrm{m} \%$; (d) $30.1-43.7 \mu \mathrm{m} \%$. Dashed lines indicate $80 \%$ coherence levels. 
relation between $30.1-43.7 \mu \mathrm{m} \%$ and kaolinite/(illite + chlorite) (Figure 4) further confirmed that 30.1-43.7 $\mu \mathrm{m} \%$ can also be used as a grain-size indicator of the East Asian winter monsoon evolution. It presents an obvious glacial-interglacial cyclicity with higher values during glacials and lower in interglacials, and the spectral analysis shows a strong 100-ka eccentricity period (Figure 6(d)), implying that the ice sheet-forced winter monsoon evolution strengthened during glacials and weakened during interglacials. Moreover, we can adopt $10.8-14.3 \mu \mathrm{m} \%$ as an indicator of East Asian summer monsoon evolution. The linear correlation between $10.8-14.3 \mu \mathrm{m} \%$ and the summer insolation of low latitude in the Northern Hemisphere implies the tropical-forced summer monsoon evolution with strengthened summer monsoon during higher insolation and weakened summer monsoon during lower insolation. We suggest that the East Asian summer monsoon has fluctuated with high frequency and been forced by changes in insolation in low latitude associated with precession and half precession, while ice-volume forcing is probably a primary factor in determining the strength and timing of the East Asian winter monsoon but with less important insolation forcing.

\section{Conclusions}

Based on the high-resolution oxygen isotope chronology and grain-size analysis of terrigenous clastics over the past $450 \mathrm{ka}$ for Core MD05-2901 in the western South China Sea, combined with the calculation of TMAR, we achieved the following conclusions:

(1) TMAR was $4.9-6.0 \mathrm{~g} \mathrm{~cm}^{-2} \mathrm{ka}^{-1}$ on average of

1 Wang P X. The South China Sea During the Last 150000 Years (in Chinese). Shanghai: Tongji University Press, 1995. 1-184

2 Wang L, Sarnthein M, Erlenkeuser H, et al. East Asian monsoon climate during the Late Pleistocene: high-resolution sediment records from the South China Sea. Mar Geol, 1999, 156: 245-284[DOI]

3 Wang P X, Jian Z M, Zhao Q H, et al. Thirty million year deep-sea records in the South China Sea. Chin Sci Bull, 2003, 48(23): $2524-2534$

4 Wang P X, Jian Z M, Zhao Q H, et al. Evolution of the South China Sea and monsoon history revealed in deep-sea records. Chin Sci Bull, 2003, 48(23): 2549-2561

5 Huang B Q, Jian Z M. Late Quaternary coastal upwelling and variations of the East Asian Summer monsoon off the eastern Vietnam interglacial stages, higher than that of glacial stages, i.e. $1.9-5.0 \mathrm{~g} \mathrm{~cm}^{-2} \mathrm{ka}^{-1}$. TMAR exhibits obvious glacialinterglacial cycles, especially since MIS 7.

(2) The two main controlling factors F1 and F2, achieved through principle component analysis of grain-size data, are responsible for $46 \%$ and $32 \%$ variation of grain-size distribution of terrigenous clastics respectively. F1 and F2 represent the changes of sea surface currents that transported materials originated from southwestern and northern continental shelves near the South China Sea respectively, implying the evolution of East Asian summer monsoon and winter monsoon.

(3) $9.26-2.66 \mu \mathrm{m} \%$ and $10.8-14.3 \mu \mathrm{m} \%$ in terrigenous clastics of Core MD05-2901 can be adopted as indicators of summer monsoon evolution, show high frequency fluctuations, and correlate well with the summer solar insolation at $15^{\circ} \mathrm{N}$. They exhibit a distinct cyclicity with frequencies near $23 \mathrm{ka}$ and $13 \mathrm{ka}$, in contrast to a strong frequency peak near $100 \mathrm{ka}$ obtained in proxies $4.24-7.42 \mu \mathrm{m} \%$ and $30.1-43.7 \mu \mathrm{m} \%$ which can be used as proxies of winter monsoon evolution. We suggest that the East Asian summer monsoon has fluctuated with high frequency and been forced by changes in solar insolation in low latitude associated with precession and half precession, while ice-volume forcing is probably a primary factor in determining the strength and timing of the East Asian winter monsoon but with less important insolation forcing.

The samples and some data used in this study were retrieved during the IMAGES XII, MD147-Marco Polo cruise of the R/V Marion Dufresne of the French Polar Institute (IPEV).

coast. Quat Res (in Chinese). 1999, 6: 518-525

6 Huang B Q, Jian Z M, Cheng X R, et al. Late Quaternary upper-water column structure in upwelling areas of the South China Sea. Chin Sci Bull, 2001, 46(20): 1741-1745

7 Jian Z, Huang B, Kuhnt W, et al. Late Quaternary upwelling intensity and East Asian Monsoon forcing in the South China Sea. Quat Res, 2001, 55: 363-370[DOI]

8 Huang B, Jian Z, Cheng X, et al. Foraminiferal response to upwelling variations in the South China Sea over the last 220000 years. Mar Micropaleontol, 2002, 47: 1-15[DOI]

9 Xiang F, Wang R J, Li J R, et al. High-resolution records of biogenic components and their paleoceanographic implications in the upwelling area of the South China Sea off eastern Vietnam over past $480 \mathrm{ka}$. 
Mar Geol Quat Geol (in Chinese), 2006, 26(6): 81-89

10 Qing Z Q, Liu L W, Zheng H B. Sedimentological and geochemical records of east Asian monsoon in summer upwelling region off the coast of Vietnam for the past 220000 years. Mar Geol Quat Geol (in Chinese), 2005, 25(2): 67-72

11 Liu Z F, Zhao Y L, Li J R, et al. Late Quaternary clay minerals off Middle Vietnam in the western South China Sea: Implication for source analysis and East Asian monsoon evolution. Sci China Ser D-Earth Sci, 2007, 50(11): 1674-1684

12 Porter S C, An Z S. Correlation between climate events in the North Atlantic and China during the last glaciation. Nature, 1995, 375: 305-308[DOI]

13 Vandenberghe J, An Z S, Nugteren G, et al. New absolute time scale for the Quaternary climate in the Chinese loess region by grain-size analysis. Geology, 1997, 25: 35-38[DOI]

14 Lu H Y, An Z. Paleoclimatic significance of grain size of loesspalaeosol deposit in Chinese Loess Plateau. Sci China Ser D-Earth Sci (in Chinese), 1998, 28(6): 626-631

15 Lu H Y, Huissteden K V, An Z S, et al. East Asian winter monsoon changes on millennial time scale before the last glacial-interglacial cycle. J Quat Sci, 1999, 14: 101－110[DOI]

16 Fang X M, Li J J, Voo R V. Rock magnetic and grain size evidence for intensified Asian atmospheric circulation since 800000 years BP related to Tibetan uplift. Earth Planet Sci Lett, 1999, 165: 129-144[DOI]

17 An Z S, Kutzbach J E, Prell W L, et al. Evolution of Asian monsoons and phased uplift of the Himalaya-Tibetan Plateau since Late Miocene times. Nature, 2001, 411: 62-66[DOI]

18 Ding Z L, Yu Z W, Yang S L, et al. Coeval changes in grain size and sedimentation rate of eolian loess, the Chinese Loess Plateau. Geophys Res Lett, 2001, 28: 2097-2100[DOI]

19 Ding Z L, Derbyshire E, Yang S L, et al. Stacked 2.6-Ma grain size record from the Chinese loess based on five sections and correlation with the deep-sea $\mathrm{O}^{18}$ record. Paleoceanography, 2002, 17(3-5): 1-20[DOI]

$20 \mathrm{Lu} \mathrm{H}$, Zhang F, Liu X. Patterns and frequencies of the East Asian winter monsoon variations during the past million years revealed by wavelet and spectral analyses. Global Planet Change, 2003, 35: $67-74[\mathrm{DOI}$

21 Gröger M, Henrich R, Bickert T, et al. Glacial-interglacial variability in lower North Atlantic deep water: inference from silt grain-size analysis and carbonate preservation in the western equational Atlantic. Mar Geol, 2003, 201: 321-332[DOI]

22 Rea D K, Hovan S A. Grain size distribution and depositional processes of the mineral component of abyssal sediments: lessons from the North Pacific. Paleoceanography, 1995, 12: 251 - 258[DOI]

23 Prins M A, Postma G, Cleveringaa J, et al. Controls on terrigenous sediment supply to the Arabian Sea during the late Quaternary: the Indus Fan. Mar Geol, 2000, 169: 327-349[DOI]
24 Prins M A, Postma G, Weltje G J. Controls on terrigenous sediment supply to the Arabian Sea during the late Quaternary: Makran contimental slope. Mar Geol, 2000, 169: 351-371[DOI]

25 Stuut J -B W, Prins M A, Schneider R R, et al. A 300-kyr record of aridity and wind strength in southwestern Africa: inferences from grain-size distributions of sediments on Walvis Ridge, S E Atlantic. Mar Geol, 2002, 180: 221 - 233[DOI]

26 Pichevin L, Cremer M, Giraudeau J, et al. A $190 \mathrm{ky}$ record of lithogenic grain-size on the Namibian slope: Forging a tight link between past wind-strength and coastal upwelling dynamics. Mar Geol, 2005, 218: 81-96[DOI]

27 Xiao S, Li A, Liu J P, et al. Coherence between solar activity and the East Asian winter monsoon variability in the past 8000 years from Yangtze River-derived mud in the East China Sea. Palaeogeogr Palaeoclimatol Palaeoecol, 2006, 237: 293-304[DOI]

28 Boulay S, Colin C, Trentesaux A, et al. Mineralogy and sedimentology of Pleistocene sediment in the South China Sea (ODP Site 1144). In: Prell W L, Wang P, Blum P, et al. Proc ODP Sci Res, 2003, 184: 1-21 [Online]. Available: http://www-odp.tamu.edu/publications/184_SR/

29 Sun D H, Bloemendal J, Rea D K, et al. Grain-size distribution function of polymodal sediments in hydraulic and aeolian environments, and numerical partitioning of the sedimentary components. Sediment Geol, 2002, 152: 263-277[DOI]

30 Weltje G J, Prins M A. Muddled or mixed? Inferring palaeoclimate from size distributions of deep-sea clastics. Sediment Geol, 2003, 162: $39-62[\mathrm{DOI}]$

31 Prins M A, Vriend M, Nugteren G, et al. Late Quaternary Aeolian dust input variability on the Chinese Loess Plateau: inferences from unmixing of loess grain-size records. Quat Sci Rev, 2007, 26: 230-242[DOI]

32 Sun Y B, Gao S, Li J. Primary analysis on the sensitive grain-size of terrigenous sediment to environments in marginal sea. Chin Sci Bull, 2003, 48(1): $83-87$

33 Laj C, Wang P X, Balut Y, et al. MD147-Marco Polo IMAGESXII Cruise Report. France: Institut Paul-Emile Victor (IPEV), 2005

34 Thompson P R, Bé A W H, Duplessy J C, et al. Disappearance of pink-pigmented Globigerinoides ruber at 120000 yr B.P. in the Indian and Pacific Oceans. Nature, 1979, 280: 554-558

35 Shackleton N J, Berger A, Peltier W R. An alternative astronomical calibration of the lower Pleistocene timescale based on ODP Site 677. Trans R Soc Edinburgh Earth Sci, 1990, 81: 251-261

36 Xie X, Zheng H B, Chen G C, et al. Pretreatment method of grain size measurement of marine sediment in paleoenvironment research. Acta Sediment Sin (in Chinese), 2007, 25(5): 511-520

37 Davies T A, Kidd R B, Ramsay A T. A time-slice approach to the history of Cenozoic Sedimentation in the Indian Ocean. Sediment Geol, 1995, 96: 157-179[DOI]

38 Huang W, Wang P X. The statistics of sediment mass in the South 
China Sea: Method and result. Adv Earth Sci (in Chinese). 2006, 21(5): $465-473$

39 Huang W. Sediment distributional patterns and evolution in the South China Sea Since the Oligocene (in Chinese). Shanghai: Tongji University, 2004. 1-112

40 Laskar J. The chaotic notion of the solar system: a numerical estimate of the size of the chaotic zoins. Icarus, 1990, 88: 266-291[DOI]

41 Paillard D, Labeyrie L, Yiou P. Analyseries 1.0: a Macintosh software for the analysis of geographical time-series. Eos, 1996, 77: 379[DOI]

42 Chappell J, Shackleton N J. Oxygen isotopes and sea level. Nature, 1986, 324: 137-140[DOI]

43 Shackleton N J. Oxygen isotopes, ice volume and sea level, Quat Sci Rev, 1987, 6: 183-190[DOI]

44 Sun X J, Luo Y L, Huang F, et al. Deep-sea pollen from the South China Sea: Pleistocene indicators of East Asian monsoon, Mar Geol, 2003, 201: 97-118[DOI]

45 Luo Y L, Chen H C, Wu G X, et al. Records of natural fire and climate history during the last three glacial-interglacial cycles around the South China Sea-Charcoal record from the ODP 1144. Sci China Ser D-Earth Sci (in Chinese), 2001, 31(10): 897-904

46 Sun J M. Provenance of loess material and formation of loess deposits on the Chinese Loess Plateau. Earth Planet Sci Lett, 2002, 203: $845-859$ [DOI]

47 Tamburini F, Adatte T, Föllmi K, et al. Investigating the history of East Asian monsoon and climate during the last glacial interglacial period (0-140000 years): mineralogy and geochemistry of ODP Sites 1143 and 1144, South China Sea. Mar Geol, 2003, 201: $147-168[\mathrm{DOI}]$
48 Wehausen R, Brumsack H-J. Astronomical forcing of the East Asian monsoon mirrored by the composition of Pliocene South China Sea sediments. Earth Planet Sci Lett, 2002, 201: 621-636[DOI]

49 Sun X J, Li X, Luo Y L, et al. The vegetation and climate at the last glaciation on the emerged continental shelf of the South China Sea. Palaeogeogr Palaeoclimatol Palaeoecol, 2000, 160: 301-316[DOI]

50 Kennett J P. Marine tephrochronology. In: Emiliani C eds. The Sea, vol. 7. New York: Wiley, 1981, 1373-1436

51 Chen G C, Zheng H B, Li J R, et al. Sedimentary records of volcanic activities in the South China Sea over the past $480 \mathrm{ka}$. Mar Geol Quat Geol (in Chinese), 2007, 27(4): 69-76

52 Li X J. Sedimentary characteristics of the Western South China Sea and their variations since the Late Pleistocene. Dissertation for the Doctoral Degree (in Chinese). Shanghai: Tongji University, 2005. 1-91

53 Milliman J D, Syvitshi J P M. Geomorphic/tectonic control of sediment discharge to the ocean: the importance of small mountainous rivers. J Geol, 1992, 100: 525-544

54 Milliman J D, Meade R H. World-wide delivery of river sediment to the oceans. J Geol, 1983, 91: 1-21

55 Selvaraj K, Chen C-T A. Moderate chemical weathering of subtropical Taiwan: constraints from solid-phase geochemistry of sediments and sedimentary rocks. J Geol, 2006, 114: 101-116[DOI]

56 Wang P, Wang L, Bian Y, et al. Late Quaternary paleoceanography of the South China Sea: surface circulation and carbonate cycles. Mar Geol, 1995, 127: 145-165[DOI]

57 Clemens S C, Prell W, Murray D, et al. Forcing mechanisms of the Indian Ocean monsoon. Nature, 1991, 353: 720-725[DOI] 